TABLE IV.

Regraduation by $\operatorname{colog} p_{x}=\mathrm{A}+\mathrm{B} c^{x}+\mathrm{D} c^{-x}$.

Comparison of Actual and Espected Deaths.

\begin{tabular}{|c|c|c|c|c|c|}
\hline $\begin{array}{c}\text { Age } \\
\text { Group }\end{array}$ & $\begin{array}{l}\text { Exposed to } \\
\text { Risk }\end{array}$ & $\begin{array}{c}\text { Expected } \\
\text { Deaths }\end{array}$ & $\begin{array}{l}\text { Actual } \\
\text { Deaths }\end{array}$ & $\underset{\text { Expected }}{\text { Actual- }}$ & $\begin{array}{c}\text { Accumulated } \\
\text { Deviation }\end{array}$ \\
\hline $11-15$ & 460 & $6 \cdot 4$ & 7 & $\cdot 6$ & .6 \\
\hline $16-20$ & 994 & $13 \cdot 1$ & 11 & $-2 \cdot 1$ & -1.5 \\
\hline $21-25$ & 2312 & $30 \cdot 4$ & 32 & $1 \cdot 6$ & -1 \\
\hline $26-30$ & 4824 & 64.8 & 54 & $-10 \cdot 8$ & $-10 \cdot 7$ \\
\hline $31-35$ & 7684 & 108.9 & 117 & $8 \cdot 1$ & $-2 \cdot 6$ \\
\hline $36-40$ & 9764 & 150.9 & 154 & $3 \cdot 1$ & .5 \\
\hline $4 I-45$ & 10626 & $186 \cdot 1$ & 185 & $-1 \cdot 1$ & -6 \\
\hline $46-50$ & 10636 & $220 \cdot 4$ & 239 & $18 \cdot 6$ & $18 \cdot 0$ \\
\hline $51-55$ & 9694 & 247.8 & 235 & $-12 \cdot 8$ & $5 \cdot 2$ \\
\hline $56-60$ & 8123 & $267 \cdot 1$ & 263 & $-4 \cdot 1$ & $1 \cdot I$ \\
\hline $61-65$ & 6230 & $272 \cdot 5$ & 271 & -1.5 & $-\quad 4$ \\
\hline $66-70$ & 4096 & $245 \cdot 8$ & 256 & $10 \cdot 2$ & $9 \cdot 8$ \\
\hline $71-75$ & 2221 & 186.0 & 172 & $-14 \cdot 0$ & -4.2 \\
\hline $76-80$ & 878 & $103 \cdot 3$ & 98 & $-5 \cdot 3$ & -9.5 \\
\hline $81-85$ & 200 & $32 \cdot 9$ & 40 & $7 \cdot 1$ & $-2 \cdot 4$ \\
\hline $86-90$ & 19 & $4 \cdot 4$ & 4 & $-\quad .4$ & $-2 \cdot 8$ \\
\hline
\end{tabular}

\title{
VALUATION OF REVERSIONS FOR ESTATE DUTY.
}

This question, which was discussed with the Inland Revenue Authorities in 1900 (see J.I.A., vol. 36, p. 81), has recently received further consideration by the Council, and the following letter was addressed to the Secretary of the Estate Duty Office on the 13 October 1927.

$$
\begin{aligned}
& \text { The Institute of Actuaries, } \\
& \text { Staple InN Hali, } \\
& \text { Holborn, W.C. }
\end{aligned}
$$

13 October 1927.

The Secretary,

Estate Duty Office,

Somerset House, W.C.2.

DeAR Sir,

\section{VALUATION OF REVERSIONS FOR ESTATE DUTY.}

We have recently had occasion to consider the question of the valuation of reversions for Estate Duty, and our attention has been drawn to the fact that there seems to be a difference of opinion in the Actuarial Profession as to the proper allowance to be made for expenses in such valuations.

This question was discussed between this Institute and the 
Estate Duty Office in December 1900, and, as the result of interviews which then took place, it was understood that your view was that while a proper deduction might be made for costs of ultimate realisation of the funds in reversion, no such allowance was appropriate for immediate costs as might be the case in a valuation for purchase.

Now that the matter is brought up for reconsideration we cannot help feeling that there was some misunderstanding in 1900. We believe that the principal value for Estate Duty purposes should be the "Price which, in the opinion of the Commissioners, such property would fetch if sold in the open market at the time of the death of the deceased", and we take this to mean the price which a purchaser would be willing to pay, and which a vendor would be willing to accept, on a sale in the open market, leaving out of account their expenses, such as stamp duty, legal expenses, etc., necessarily incidental to the sale and purchase.

We should be much obliged if you would kindly consider the matter and let us know whether our present interpretation of the position is correct, so that we may be in a position to give a ruling on the point to our Members.

We are, Dear Sir,

Yours faithfully,

\author{
(Sgd.) H. E. MELVILLE. \\ H. J. P. OAKLEY, \\ Hon. Secretaries.
}

In reply to this letter the Council were informed that "the " principal value of property (including a reversion) for the purposes "of Estate Duty is the price which that property would fetch, as " between a willing Vendor and willing and competing purchasers in " the open market, without adjustment for any expenses incurred " by the Vendor in connection with his sale or any expenses incurred " by the purchaser in connection with his purchase."

From this it will be seen that the views of the Revenue Authorities coincide with those of the Council. 